\title{
Science in China to face its biggest upheaval since mid-1970s reforms
}

London. In a move which reflects concerns in the West over linking science to wealth creation, the Chinese government has told scientists in a 700-page white paper that most of the country's research laboratories are to be turned into business units aimed at fuelling economic growth.

The document, whose publication coincides with the sixth anniversary of the Tiananmen Square massacre, also announces plans to spend 80 per cent of China's research budget on "agriculture and industry", and the diversion of 100,000 scientists to "scientific and technological work geared to economic construction".

But government officials claim that they do not intend to neglect basic research. Song Jiang, minister of the state science and technology commission, promised last week that spending on basic research would double to 10 per cent of China's total research budget by the year 2000 .

The white paper, said to be the most radical overhaul of Chinese science for almost two decades, carries the stamp of the Chinese president, Jiang Zemin, and other senior members of the Communist party. It confirms earlier announcements that China's science budget will treble from 0.5 per cent of gross domestic product to 1.5 per cent by the year 2000 . (see Nature 375, 175; 1995). The paper's overall proposals are expected to be put into place next year at the beginning of China's twelfth national five-year plan.

Addressing a specially convened five-day national conference on science and technology in Beijing last week, China's vicepremier, Li Peng, said that, from next year, basic research is to be concentrated among "a group of élite scientists". The rest of the country's researchers, he said, "should merge themselves with businesses", or turn themselves into "financially and developmentally independent businesses providing scientific and technological services".

In his opening remarks, Jiang Zemin said the changes were needed to introduce competitiveness in science "in accordance with the ideals of a socialist-market economy". $\mathrm{He}$ added that "scientific and technological work should always make economic construction its main theatre of operations".

The emphasis on applied science, according to the Chinese president, has already "made outstanding contributions to promot-

\section{IMAGE UNAVAILABLE FOR COPYRIGHT REASONS}

\section{Peng (left): concentrating China's basic research among 'a group of élite scientists'; others should look to business, he says.}

ing economic and social development, enhancing overall national strength and improving the people's living standards".

The white paper also coincides with a report from the Australian National Academy predicting that China will be the world's second-largest economy and among the leading six trading nations by the year 2005. China has recorded double-digit growth for six years in succession since 1989.

Reactions to the white paper, which effectively amounts to a reversal of a 1978 white paper that sought to strengthen basic research, have been mixed. Not surprisingly, it lacks the wholehearted endorsement of the 90,000-member Chinese Academy of Sciences. The 120-institute academy - the oldest and largest centre of research in the country - has watched its funding decline over the past decade, and will effectively be broken up if the proposals go ahead. Its

\section{Yeltsin promises to boost research budget}

Moscow. Russian president Boris Yeltsin, speaking at the first meeting of the newlycreated Council for Science and Technology Policy, has promised to increase funding for science to three per cent of total government expenditure in 1996.

In his speech, Yeltsin said that it was important that the funds available for science were increased. But he also said that greater efforts should be made to attract funding for private sources and to develop scientific discoveries into commercially exploitable products.

Yeltsin also repeated his call for a coherent science policy that would include an acknowledgement of the 'strategic aspects' of scientific and technological development, including the need to ensure adequate supplies of trained scientists, technicians and engineers. members are said to be unhappy at the document's apparent emphasis on technology at the expense of basic research.

In a rare public expression of dissent, Zhou Guangzhao, the academy's president, has warned China's leaders in an article in the Communist party newspaper, Renmin

Ribao, that economic growth cannot be achieved without investing in basic research. Cutting back on it, he said, would be a waste of rare scientific talent, and is already contributing to the brain drain.

Others doubt how far the white paper's proposals will be put into practice. Fang Lizhi, for example, the physicist who was a key figure in drafting the 1978 white paper and later become involved in protests at government actions, is deeply suspicious.

Fang, who now teaches particle physics at the University of Arizona, believes the drive to turn laboratories into autonomous enterprises is motivated by a desire to dismember, and thus silence, the once powerful academy, a continuous source of criticism of government policy.

He points out that more than 20 of the academy's most senior members, including $\mathrm{Xu}$ Liangying, a prominent historian of science, and Wang Ganchang, father of China's nuclear programme, wrote an open letter to the government last month calling for greater democracy and human rights (see Nature 375, 269; 1995)

He also adds that, unlike the 1978 document, the new white paper is thin on detail. "There's far too much rhetoric and ideology," he says, claiming that the white paper is "obsessed" with applied research. "Back in 1978 , we had the right balance between pure and applied science," says Fang. "Now, they're damaging a lot of institutions by turning them into businesses."

But Peter Suttmeier, director of the Centre for Asia and Pacific Studies at the University of Oregon, warns against dismissing the document as "just another piece of rhetoric". The white paper, he says, is much too significant to be dismissed as a conspiracy against the academy, which has recently had its budget cut substantially, and has to compete for funds with the newly-established National Science Foundation.

"A lot of institutions that were at the heart of academic life in China are now at risk because of reform policies," says Suttmeier. "The academy is the sort of institution that had a certain logic in a Sovietstyle economy. But it has no relevance to the marketplace, and the Chinese face a dilemma over what to do with it." Ehsan Masood 